\title{
Land Development and Community Benefits
}

\author{
Professor Victor Moore*
}

In 1992, the market leaders in the food retailing business J. Sainsbury p.1.c. and Tesco Stores Ltd. were each granted planning permission by Plymouth City Council, the local planning authority for the City, for the erection of a superstore on the City's outskirts. Both permissions were dependent upon the companies entering into an agreement under section 106 of the Town and Country Planning Act 1990 (as amended) whereby each company covenanted to provide, or provide funding for, various projects which formed no part of the development itself. In particular, J. Sainsbury p.l.c. agreed to provide the City with a tourist information centre, an art gallery display and a bird-watching hide. They also agreed to make contributions towards the development of the City's park and ride facilities and a much needed increase in the City's creche provision for working mothers. The total cost to the Company of meeting these and other covenants was to be in excess of $£ 3.6 \mathrm{~m}$. Likewise, Tesco Stores Ltd. too, agreed to provide, following the grant of planning permission, a variety of benefits not directly related to the development for which the company had applied.'

For many years planning policy and planning law have both sought to limit the situations where a developer can be required to provide planning benefits before being granted planning permission to those situations where the benefit will overcome some objection to the proposed development. Thus, for example, it is not uncommon for developers to be granted planning permission only when they have agreed to pay for improvements to be made to a nearby (off-site) road junction needed to accommodate the increase in traffic likely to be generated by their proposed development, or to pay for a new sewer which would be needed if proposed development were to take place. The principle seemed to be adequately formulated in para.B7 of the Department of the Environment Circular No. 16/91 "Planning Obligations" which states:

"Planning obligations should only be sought where they are necessary to the granting of [planning] permission, relevant to planning and relevant to the development to be permitted."

* Department of Law, University of Reading.

1. Somewhat exceptionally the terms of the proposed arrangements were included as an appendix to the judgment of Hutchinson $\mathrm{J}$ in the High Court. 
The philosophy is clear. To hold otherwise would be to open the door to the sale of planning permissions. Given the severe restrictions which have been placed on public expenditure, local authorities might otherwise be tempted in return for an extraneous benefit to grant planning permission for development in respect of which there was a genuine planning objection.

The Plymouth supermarkets scenario was somewhat exceptional in that in the City Council's view there was no planning objection to the building of both stores; it must therefore follow that even though the Council took the developers' undertakings into account in deciding to grant planning permission for the stores, permission would still have been granted if no such undertakings had been given.

Not surprisingly, the third major food retailer present in the area, the South Devon Co-operative Society, sought (albeit unsuccessfully) both in the High Court and the Court of Appeal to challenge the Council's decision. The Society had found themselves faced with two competitors, where as previously they had anticipated there would, at most, be only one. Their main complaint to the Court was that the City Council had acted unlawfully by taking into account an immaterial consideration, namely the offer by their competitors to provide the City council with extraneous benefits. They argued that in order for a benefit to be taken into account, it had to be "necessary", in that it must overcome what would otherwise be an objection to the development. Without that effect it was claimed, planning permission should have been refused.

\section{Historical background}

The source of modern day British planning law was the Town and Country Planning Act 1947. For the first time, every parcel of land was then made subject to planning control, so that with minor exceptions, any land-owner wishing to develop his land had first to obtain planning permission from the local planning authority. It was foreseen that such controls would play havoc with land values; hence the Act contained elaborate provisions to compensate all those affected, whilst at the same time ensuring that subsequent increases in the value of land due to planning decisions were to accrue to the State. The effect of the provisions was to tax all development value in land created after the Act came into force at a rate of 100 per cent, irrespective of whether the increases were created as a result of restrictive planning policies imposed elsewhere, or by infrastructure provision such as roads, schools, hospitals etc. provided from the public purse and without which the land would not be a marketable development proposition. Logical though the Act's financial provisions may have been however, the tax (known as the development charge) was abolished in $1953^{2}$ by an incoming Conservative administration.

In due course further attempts were made, mainly by Labour administrations, through the Land Commission Act 1967 and the Development Land Tax 1976, to recoup for the community through a specific tax, part of the development value of the land 
which would have otherwise accrued to a landowner from a grant of planning permission to develop. Both Acts were subsequently repealed by Conservative administrations. Today, there is no special tax payable on development value; although in rare cases an owner may be liable to pay capital gains tax on land value if he realises a capital gain on the disposal of such land.

Increase in land value may arise from other sources. In particular, occupiers such as food retailers benefit, once planning permission has been granted for development for retail purposes, from the ability to secure increased trading profits. The offers by both J. Sainsbury p.l.c. and Tesco Stores Ltd. were presumably made out of their anticipated increased trading profits, the increase in the value of the land due to the grant of planning permission having mainly benefited the land owner.

\section{Planning agreements}

The grant of planning permission to carry out development has been described as "a licence to print money". It is not surprising, therefore, that impecunious local authorities have sought other means to secure that developers themselves, out of development or other profits, contribute towards the public expenditure needed to facilitate new development. In the absence of any special tax on development value however, the attention of local planning authorities began to turn toward the little known section 52 of the Town and Country Planning Act 1971 (subsequently to be consolidated as section 106 of the Town and Country Planning Act 1990) which gave power to a local planning authority to ". . . enter into an agreement with any person having an interest in land in their area for the purpose of restricting or regulating the development or use of land, either permanently or during such period as may be described by the agreement".

There is some evidence that the power was originally intended to provide authorities with a mechanism for controlling the development of land before statutory development plans for their area had been prepared and approved. Indeed, until the late 1960s, very few agreements were entered into. In the late 1970s, however, the position began to change dramatically, and there was evidence that this statutory provision was being used in a way quite unconnected with its original purpose. Local planning authorities saw the provision as an opportunity for obtaining 'planning gain' for their community. In some cases, the grant of planning permission was made conditional upon the applicant entering into a planning agreement. So no agreement, no planning permission. In return for the grant of planning permission, the developer would be expected to enter into an agreement to provide some public benefit, which might or might not be related to the development for which planning permission was to be granted. He might, for example, be required to contribute towards the provision of infrastructure or the restoration of a listed building or church, or to provide public amenities such as open spaces or community centres.

For the most part planning agreements were sought and obtained for a proper and legitimate planning purpose. Occasionally however, planning agreements were sought for purposes which could be considered of most doubtful legality. Examples might 
include a requirement that the applicant provide new roads or sewers in excess of that required to serve the additional demand generated by the particular development in question; or that he provide at his own expense local authority housing; or that he be allowed an increase in the density or plot ratio normally permitted in return for the dedication of land as open space or as a footpath.

It will be seen that the use of planning agreements linked to the grant of planning permission can raise both moral and legal issues. It raises a moral issue when used by a local planning authority to circumvent the general principle that landowners are entitled to planning permission for the development of their land unless there is a substantial planning objection to the development, by the addition of a requirement that they should contribute something in return for that entitlement. It raises a legal issue in the sense that there is vagueness and uncertainty over the extent of authorities' power to require a planning agreement to be entered into as part of a 'planning permission package'. It is not surprising, therefore, that during the late 1970 s, commentaries on the use of section 52 agreements were sometimes characterised by such terms as 'the sale of planning permissions' or 'cheque-book planning'; and in severe cases, their use was regarded by developers as little short of blackmail.

On the other hand, the system was not universally disliked by developers. The giving of a public benefit was often seen as a small price to pay in return for a grant of planning permission, and often enabled development which would otherwise have been controversial to be more readily accepted by the community. This may explain why so few attempts have been made to challenge such agreements in the courts.

In 1980, the growing use of planning agreements together with uncertainty about the legal and administrative contours within which they should operate, persuaded the Government to ask a body called the Property Advisory Group to consider and report on the arrangements whereby local planning authorities, in granting planning permission, achieve planning or amenity gains at the expense of the developers.

Following the Group's report, Planning Gain, the Department of the Environment issued Circular No. 22/83 giving guidance and advice on how far it is proper for a local planning authority to seek from a developer benefits which go beyond the development for which planning permission is being sought. The Circular said that authorities are not entitled to treat an applicant's need for planning permission as an opportunity to obtain wholly extraneous benefits from the developer. According to the Circular, the reasonableness of asking the developer to accept an obligation over and above his development proposals depended substantially on whether what was required:

(a) was needed to enable the development to go ahead, e.g., provision of adequate access, water supply, sewerage and sewage disposal facilities;

(b) in the case of financial payments, would contribute to meeting the cost of providing such facilities in the near future;

(c) was otherwise so directly related to the proposed development and to the use of land after its completion that the development ought not to be permitted 
without it, e.g., the provision, whether by the developer or by the authority at the developer's expense, or car-parking in or near the development or of reasonable amounts of open space related to the development; or

(d) was designed in the case of mixed development to secure an acceptable balance of uses.

Where those tests were met two others were to be applied. They were whether:

(a) the extent of what was required was fairly and reasonably related to scale and kind to the proposed development;

(b) what the developer was being asked to provide or help to finance represented in itself a reasonable charge on the developer as distinct from being financed by national or local taxation or other means (e.g., as a charge on those using the facility provided).

The Circular reminded authorities which sought to impose unreasonable obligations in connection with a grant of planning permission that the developer was entitled to refuse to accept the demands being made and to appeal to the Secretary of State against any subsequent refusal of permission or imposition of a condition or the nondetermination of the application.

In 1991, Circular No. 22/83 was cancelled, and a new Circular No. 16/91 "Planning Obligations" issued consequent upon the abolition of "planning agreements" and their replacement by what are now known as "planning obligations".

\section{Reasons for the change}

One of the problems with planning agreements was that only the developer and local planning authorities could be parties to it. A developer was not obliged to enter into an agreement and if a local planning authority decided to hold out for one, the developer could only appeal against non-determination of the application or its refusal, whichever was the case. The Inspector or the Secretary of State might then conclude, however, that permission could be given if there was an agreement which allowed the objection to the development to be removed which could not be achieved by the imposition of a condition. In such cases, the only action the Inspector could take, apart from refusal, was to suggest that an agreement might be entered into. This was unsatisfactory, however, since on the one hand the Inspector or Secretary of State could not specify the terms of such an agreement which was a matter for negotiation between the parties; and, on the other, the developer might be unable to reach agreement on its terms with the local authority.

Accordingly, the Government decided that there should be statutory provision to enable a developer to give a unilateral undertaking, which would be binding on him and on successors in title, to carry out certain works or to do whatever the undertaking may specify. The advantage of such an undertaking, which would be enforceable by the local authority, was that it would not be necessary for the local planning authority to agree the terms. In considering the related planning application or appeal, the 
authority or the Secretary of State respectively would be required to have regard to the terms of any unilateral undertaking offered by the developer (or any agreement into which he was willing to enter), and the developer would be able to give further undertakings (or offer to enter into further agreements) during the course of appeal proceedings.

\section{Planning obligations}

When planning legislation was consolidated in 1990, section 52 of the Town and Country Planning Act 1971 became section 106 of the Town and Country Planning Act 1990 . A year later the section was repealed by the Planning and Compensation Act 1991 and new section 106, 106A and 106B containing the provisions relating to planning obligations, was substituted in its place. The new section 106, amended the law relating to 'planning agreements' by enabling a developer to enter into a 'planning obligation', which may be done either by agreement with the authority, or by the developer giving a unilateral undertaking. It was undertakings under this provision by J. Sainsbury p.1.c. and Tesco Stores Ltd. that was the issue in the Plymouth case.

The new section 106 of the 1990 Act provides that any person interested in land in the area of a local planning authority may, by agreement or otherwise, enter into an obligation (defined as 'a planning obligation'). It provides that such obligation may restrict the development or use of land in some specified way; require specified operations or activities to be carried out in, on, under or over land; require the land to be used in some specified way; or require a sum or sums to be paid to the authority on a specified date or dates or periodically. It is interesting to note that the new section sets out in rather more detail than did the old purpose of a planning obligation and for the first time also, there is a statutory recognition that an obligation may include an undertaking to make cash payments.

Consequent upon these legislative changes, the Department of the Environment revoked the earlier Circular No. 22/83 "Planning Gain" and in Circular No. 16/91 "Planning Obligations", issued guidance on the operation of the new legislative provisions. The new Circular explained the changes made by new provisions, but contained no substantial departures from the general policy previously set out in the old Circular which it had replaced. It did however, on matters of detail, enlarge the rules as to what the Secretary of State would consider reasonable where local planning authorities sought to impose obligations on developers under the new provisions. In particular, the new Circular contemplates developers contributing not only to the cost of physical infrastructure directly related to the proposed development, but also the cost of social infrastructure such as "social, education, recreation, sporting and other community provision, the need for which arises from the development." ${ }^{13}$ In addition, the new Circular envisaged that obligations might be used to "offset the 
loss of impact on any amenity or resource present on the site prior to development, for example in the interests of nature conservation."

\section{The Plymouth decision}

Section 70(2) of the Town and Country Planning Act 1990 provides in determining an application for planning permission, the local planning authority "shall have regard to the provision of the development plan, so far as material to the application, and to any other material consideration." The Devon Co-operative Society's case was that the City Council had acted unlawfully by taking into account immaterial considerations, namely the offers by the other two food retailers to provide some or all of the community benefits. The Society argued that in order for a benefit to be taken into account it had to be "necessary", that is, needed in order to overcome what would otherwise be a planning objection to the development or some harm which would flow from it. Both the High Court and the Court of Appeal rejected the Society's argument. A unanimous Court of Appeal held that the test of materiality was (as with a condition imposed in a grant of planning permission ${ }^{4}$ ) threefold, namely it had to serve a planning purpose; it had to fairly and reasonably relate to the development permitted; and it had not to be Wednesbury unreasonable. In dismissing the applicants' challenge to the decision of the Plymouth City council to grant planning permission to J. Sainsbury p.l.c. and Tesco Stores Ltd. the Court of Appeal held that all the benefits offered by the two respondent companies met that threefold test.

The decision of the Court of Appeal is likely to have far-reaching consequences. It now seems that in determining applications for planning permission, a local planning authority can now take into account any benefit (incuding those extraneous to the development applied for) provided that it fairly and reasonably relates to the permitted development; the benefit no longer has to be one whose absence would justify the refusal of planning permission. The decision means that the advice contained in Circular No. $16 / 91$ is at best, inaccurate. At worst, it indicates an avenue whereby the test currently laid down in the Circular can be circumvented by a developer anxious to secure planning permission from a local planning authority anxious to obtain a contribution from developers to meet the cost of other development projects. Above all, the decision must raise the spectre of planning permission being bought and sold, particularly where the scales between a grant or refusal of planning permission are evenly balanced.

Concern that this is a real possibility is seen in an even more recent decision than that in the Plymouth case. The precise limits on the ability of a local planning authority (or the Secretary of State on appeal) to require or receive community benefits in excess of what is necessary to enable the development to proceed is now in total disarray, which only the House of Lords or Parliament can correct. As it happens, the House of Lords are to be allowed the first try since as this journal goes to press, the House

4. See Viscount Dilhorne's three tests in Newbury District Council v. Secretary of State (1981) A.C. 578 , at p.599. 
of Lords have granted Tesco leave to pursue their appeal, after it having been refused by the Court of Appeal.

In Tesco Stores Ltd v Secretary of State for the Environment and West Oxfordshire District Council and Tarmac Provincial Properties Ltd. ${ }^{5}$ Tesco and Tarmac had both sought planning permission to build a retail store on the outskirts of Witney in Oxfordshire. Following a public inquiry into both proposals, the Inspector recommended permission for Tesco bot not for Tarmac. Contrary to those recommendations the Secretary of State refused Tesco's application and granted Tarmac permission. In an application to quash the decision, Tesco argued that the Secretary of State had erred in not considering an offer by Tesco to fund a new road to the west of the town on the ground that the relationship between the road and the proposed store was tenuous. The Secretary of State had incorrectly applied to that offer an inappropriate test of necessity, rather than regarding it as one more material consideration to be taken into account.

Although successful in the High Court (where the judge applied the Plymouth decision), the Court of Appeal found for the Secretary of State on the ground that although he must have concluded that the offer of funding was material, he had given the offer no weight. Steyn LJ, however, thought that the Secretary of State's reasoning could not easily be reconciled with the decision in the Plymouth case, which he considered had "obliquely destroyed the core of the circular" and "became perilously close to emasculating the principle that planning permission may not be bought and sold." 